\title{
Factors That Compromise the Nutritional Value of Cowpea Fluor and Its Protein Isolates
}

\author{
Ikhlas Ibrahim Khalid1, Sirelkhatim Balla Elhardallou ${ }^{2 *}$ \\ ${ }^{1}$ Faculty of Science, Shagra University, Riyadh, Saudi Arabia \\ ${ }^{2}$ Department of Chemistry, Faculty of Science, Taif University, Taif, Saudi Arabia \\ Email: "drhardallou@yahoo.com
}

Received 6 February 2016; accepted 23 February 2016; published 26 February 2016

Copyright (C) 2016 by authors and Scientific Research Publishing Inc.

This work is licensed under the Creative Commons Attribution International License (CC BY). http://creativecommons.org/licenses/by/4.0/

c) (7) Open Access

\begin{abstract}
Anti-nutritional studies on cowpea (Vigna ungiculata L.) seeds as whole cowpea flour (WCF), dehulled cowpea flour (DCF), dehulled defatted cowpea flour (DDCF) and protein isolates obtained from DDCF by isoelectric (CPIA) and micellization (CPIB) precipitation. The protein content of WCF and DDCF were $22.3 \%$ and $26.75 \%$ respectively, while CPIA and CPIB showed $75 \%$ and $76 \%$ respectively. The abundant minerals in WCF and DCF were calcium $(32.38-33.61 \mathrm{mg} / 100 \mathrm{~g})$; potassium (29.25 - $24.99 \mathrm{mg} / 100 \mathrm{~g})$; and sodium $(1.76-1.00 \mathrm{mg} / 100 \mathrm{~g})$. The least abundant minerals were iron $(0.004-0.013 \mathrm{mg} / 100 \mathrm{~g})$; copper $(0.04-0.25 \mathrm{mg} / 100 \mathrm{~g})$; manganese $(0.18-0.30$ $\mathrm{mg} / 100 \mathrm{~g})$ and zinc $(0.26-1.22 \mathrm{mg} / 100 \mathrm{~g})$; respectively. Trypsin inhibitor activity for WCF, CPIA and CPIB was found 16,640 TIU/g, $4293 \mathrm{TIU} / \mathrm{g}$ and $4290 \mathrm{TIU} / \mathrm{g}$ respectively. Condensed tannins in RCF and DDCF were found $0.003 \%$ and $0.004 \%$ respectively while phytic acid content $0.8 \%$ and $\mathbf{1 . 1 7 \%}$ respectively, no phytic acid and tannins were observed in protein isolates. Cowpea flour was also similar to other edible grain legumes in content of anti-nutritional factors; appropriate processing methods improved cowpea nutritive value and significantly reduced the levels of antinutritional factors.
\end{abstract}

Keywords

Cowpea, Protein Isolates, Anti-Nutritional Factors

\section{Introduction}

Legume seeds are important source of protein, supplement cereals not only for protein, but also for minerals and

*Corresponding author. 
vitamins of B complex; the Legumes also provide additional nicotinic acid and minerals. Legumes together with cereals are the main plant source of proteins in human diet. They are also rich in dietary fibre and carbohydrates [1].

Cowpea (Vigna unguiculata L. Walp) is an important legume crop in most part of the world and is of health benefit in addition to the nutritional potential.

In addition to dietary fiber, cowpeas contain many health-promoting components such as vitamins, minerals and phytochemicals, which include phenolic compounds which are antioxidants with ability to prevent degenerative diseases (heart diseases and cancer) [2].

The partial replacement of animal foods with legumes improves nutritional status [3] due to lower cholesterol level in plant foods. Plant food diets increase the level of fibre intake, which reduces the risk of bowel diseases, including cancer and reduction in osteoporosis incidence [4]. High protein (18\% - 35\%) and carbohydrates (50\% - 60\%) contents together with amino acid pattern complementary to that of cereal grains, however, make cowpea a potentially important nutritional component in the human diet [5]. The protein nutritive value of cowpea is lower than that of animal proteins.

Factors contributing to the poor protein quality include poor digestibility, deficient of sulfur amino acids and present of anti-nutritional factors (phytate, polphenols), enzyme inhibitors (trypsin, chymotrypsin). Several studies show that physical treatments, including de-hulling, soaking, cooking, thermal treatments, irradiation and protein fractionation, moreover, germination and fermentation, lead to reduce anti-nutritional compounds [6], [7]. Cowpea protein concentrates and isolates can be utilized in the production of several conventional food formulations to increase their protein content as well as in the production of textured foods.

The aim of this study is to study the effect of de-hulling on the possible reduction or inactivation of some anti-nutrient factors (tannins, phytic acid and trypsin inhibitors) in raw cowpea flour and protein isolates.

\section{Materials and Methods}

Samples: Dehulled cowpea (Vigna unguiculata L. Walp) of white coloured seed (Figure 1), brought from the local market at Wad Medani city, Sudan. The seeds were stored in polyethylene bags at room temperature $\left(29^{\circ} \mathrm{C}\right.$ $30^{\circ} \mathrm{C}$ ) until used.
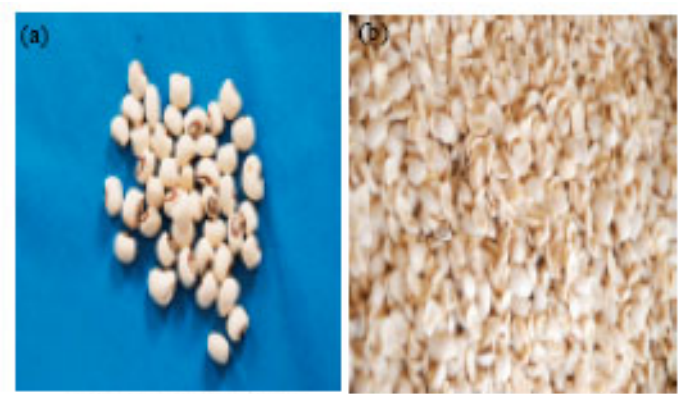

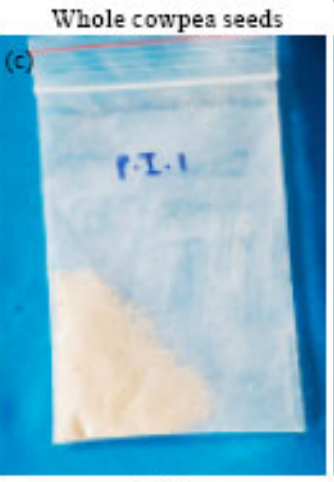

CPIA
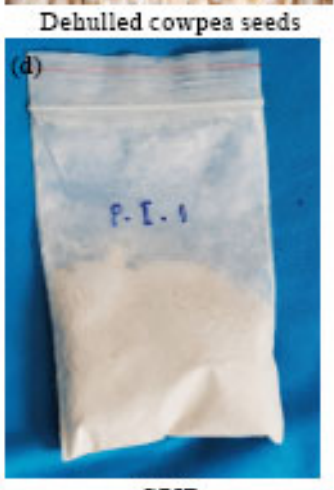

CPIB

Figure 1. (a)-(d): Cowpea seeds and protein isolates, CPIA: Cowpea protein isolate prepared by isoelectric precipitation, CPIB: Cowpea protein isolate prepared by micellization precipitation. 


\subsection{Preparation of Cowpea Seed Flours}

The dehulled cowpea seeds, ground to pass through a 35 mesh. The flour was defatted by soaking in petroleum ether (BP. $40^{\circ} \mathrm{C}-60^{\circ} \mathrm{C}$ ), at room temperature for $48 \mathrm{~h}$ with several changes of the solvent. The solvent, decanted and the defatted flour was air dried over night at room temperature, kept in clean bottles at room temperature ready for analysis.

Protein isolates preparation: Preparation of protein isolate (PI) by isoelectric precipitation (CPIA): Protein isolate-A, (CPIA) was prepared from cowpea seed flour as shown in Figure 2; following the method described by [8], slightly modified [9] [10]. The insoluble matrices, separated by refrigerated centrifuge at $4 \times$ $103 \mathrm{~g}$ for $20 \mathrm{~min}$ and discarded. The extraction and centrifugation procedures were repeated on the residue. The supernatant, adjusted to $\mathrm{pH} 4.0$ with $1.0 \mathrm{~N} \mathrm{HCl}$ and stirred at room temperature for $20 \mathrm{~min}$. The mixture, centrifuged in a refrigerated centrifuge $\left(4000 \mathrm{~g}^{-1} 20 \mathrm{~min}\right)$. The precipitate washed by distilled water several times until it was free from the salt and then neutralized by $1.0 \mathrm{~N} \mathrm{NaOH}$ to $\mathrm{pH}$ 7.0. The neutralized precipitate left over night in refrigerator $\left(4.0^{\circ} \mathrm{C}\right)$. The isolate, dried using freeze-drying and then ground into powder using a ceramic mortar and pestle and finally stored in a desiccators at room temperature until analysis.

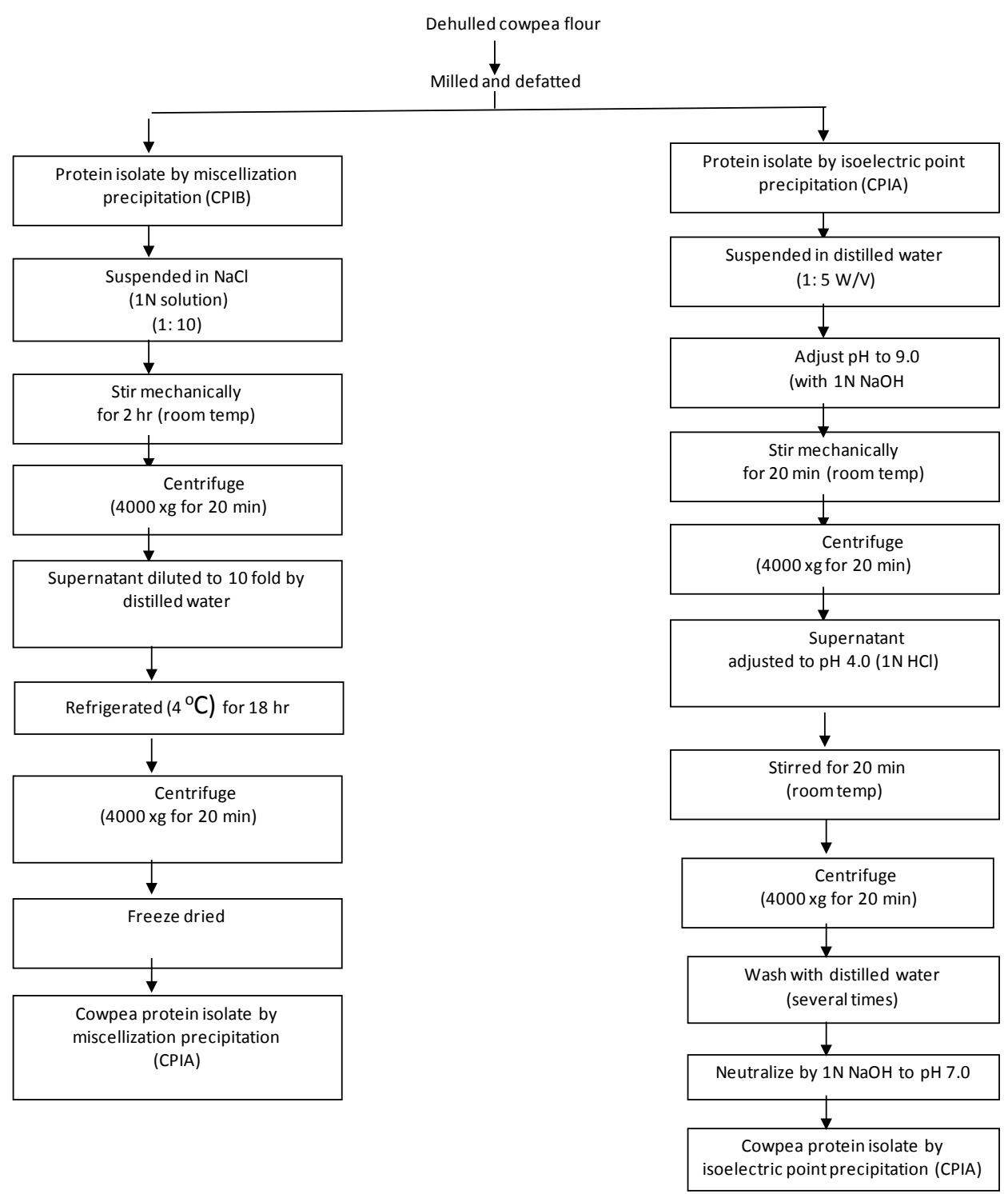

Figure 2. Preparation of cowpea protein isolates by isoelectric (CPIA) and micellization precipitate (CPIB). 
Preparation of protein isolate (PI) using micellization precipitation (CPIB): Preparation of protein isolate-B using micella method, presented in Figure 2 as described by [11]. The defatted seed flour, suspended in $\mathrm{NaCl} 1.0 \mathrm{~N}$ solution in a 1:10 (w/v) ratio, then stirring for $2 \mathrm{~h}$ at room temperature. The suspension was centrifuged at $3000 \times \mathrm{g}$ for $30 \mathrm{~min}$ and then the residue was extracted again as described above. The combined supernatant was diluted ten folds by distilled water and left to stand at refrigeration temperature $\left(4^{\circ} \mathrm{C}\right)$ for $\left.18 \mathrm{~h}\right)$.

Chemical analysis: Cowpea seed flour and protein isolate composition were determined following methodology for total nitrogen (Kjeldahl), fat (Soxhlet), carbohydrates, moisture and ash (gravimetrically) and crude fibre by a chemical-gravimetric method [12] and the means reported on dry weight basis.

Total tannins are determined by vanillin method as described by [13]. $200 \mathrm{mg}$ of ground sample of each dehulled defatted cowpea seed flour (DDCF) and protein isolate (CPIA and CPIB) was extracted, within a day after grinding, with $10 \mathrm{ml}$ methanol, in a desk top centrifuge. The test tube containing the sample, capped and continuously shacked for $20 \mathrm{~min}$ and then centrifuged at $2500 \mathrm{rpm}$ for 5 minutes.

Vanillin reagent prepared fresh daily by mixing equal volumes of $1 \%$ vanillin in methanol and $8 \%$ concentrated $\mathrm{HCl}$ in methanol is added $(5 \mathrm{ml})$ at 1 -min intervals to $1 \mathrm{ml}$ aliquots of the samples. The blanks were prepared by adding $5 \mathrm{ml}$ of $4 \%$ concentrated $\mathrm{HCl}$ in methanol to $1 \mathrm{ml}$ aliquot of the sample. Absorbance, read on spectrophotometer (Shimadzu UV-1201) at $500 \mathrm{~nm}$. Readings, taken after 20 min for the tubes remaining in the water bath maintained at $30^{\circ} \mathrm{C}$. Absorbance of the blank, subtracted from the absorbance with vanillin. Tannin concentration, expressed as catechin equivalent (C.E) as follows:

$$
\text { C.E\% }=\frac{C \times 10 \times 100}{200}
$$

where: $C=$ Concentration corresponding to the optical density.

$10=$ Volume of extract (ml); 200 = Sample weight (mg).

\subsection{Determination of Phytic Acid}

Phytic acid was determined according to the method described by [14] using chromogenic solution. Forty-five milliliters of methanol, mixed with $25 \mathrm{ml}$ of distilled water and $25 \mathrm{ml}$ of solution C. This solution was stable at least three months when stored at $4^{\circ} \mathrm{C}-5^{\circ} \mathrm{C}$.

Solution B: Forty milliliters of concentrated $\mathrm{HCl}$ and $10 \mathrm{ml}$ of elemental mercury, shaken with $80 \mathrm{ml}$ of solution A for 30 min. Filtered using Whatman No. 1 filter paper and the filtrate used.

\subsection{Anti-Nutritional Factors: Tannins (as Tannic Acid)}

Solution C: Exactly two hundred milliliters of concentrated sulfuric acid, added carefully to the remainder of solution A and mixed with filtrate of solution B.

\subsection{Extraction of Phytate}

A sample $(0.5 \mathrm{~g})$ of defatted cowpea flour, placed in a 125-ml Erlenmeyer flask and extracted with $25 \mathrm{ml}$ of $3 \%$ trichloroacetic acid for $45 \mathrm{~min}$. using a shaker of moderate speed at room temperature. Eight milliliters of the slurry, centrifuged at $2 \times 104 \mathrm{~g}$ for $15 \mathrm{~min}$ at $23^{\circ} \mathrm{C}$ three milliliters of $1.0 \mathrm{~N} \mathrm{HC1}, 3 \% \mathrm{FeCl} .6 \mathrm{H}_{2} \mathrm{O}$ in $1.0 \mathrm{~N} \mathrm{HCl}$ was added to $5 \mathrm{ml}$ of supernatant and heated in a boiling water bath for $45 \mathrm{~min}$; allowed to cool and centrifuged at 2 x $104 \mathrm{~g}$ for $10 \mathrm{~min}$. The precipitate ferric phytate, suspended in $0.5 \mathrm{~N} \mathrm{HCl}$ and incubated at room temperature $\left(30^{\circ} \mathrm{C}\right)$ for $2 \mathrm{hr}$. The precipitate, washed twice with $0.5 \mathrm{~N} \mathrm{HCl}$ allowing $10 \mathrm{~min}$ incubation period between each wash. Three milliliters of $1.5 \mathrm{~N} \mathrm{NaOH}$ and $7 \mathrm{ml}$ of distilled water, added to the precipitate ferric phytate and heating in a boiling water bath for $15 \mathrm{~min}$; cooled and centrifuged for $15 \mathrm{~min}$; the supernatant was used for estimation of phytate.

\subsection{Determination of Extracted Phytate}

Extracted phytate $(0.2 \mathrm{ml})$, mixed with $4.6 \mathrm{ml}$ of distilled water and $0.2 \mathrm{ml}$ of chromogenic solution; heated in water bath at $\left(95^{\circ} \mathrm{C}\right)$ for $30 \mathrm{~min}$.; allowed to cool and the absorbance was recorded at $830 \mathrm{~nm}$. The concentration of phytate was determined by using calibration curve constructed by solution containing known concentrations of sodium phytate from Sigma Company, (purity 97\%) containing 12 Na per mol from corn (Type V) as pre- 
pared by dissolving $11.740 \mathrm{mg}$ and the volume adjusted to $100 \mathrm{ml}$ using distilled water.

\subsection{Trypsin Inhibitors}

The method [15], used to estimate trypsin inhibitors in cowpea seed flours and protein isolates. One g sample was extracted with $50 \mathrm{ml}$ of $0.01 \mathrm{~N} \mathrm{NaOH}$ (the $\mathrm{pH}$ adjusted, when required, to (8.4 - 10.0) for $3 \mathrm{hr}$. stirring, sufficient to keep the sample in suspension. This suspension, then diluted so that $2 \mathrm{ml}$ of the sample extract inhibited $40 \%-60 \%$ of the trypsin used as standard in the analysis. To each of the four test tubes, 2-ml aliquots of the diluted sample extract added with a wide-tip pipette. A fifth tube was prepared for the trypsin standard by adding $2 \mathrm{ml}$ of distilled water. To three of the four tubes containing the sample extract and the tube containing distilled water, $2 \mathrm{ml}$ of trypsin solution was added, and the tubes were placed in a constant temperature bath $\left(37^{\circ} \mathrm{C}\right)$ for $10 \mathrm{~min}$. Five ml of Benzoyl-DL-argnine-p-nitroanalide hydrochloride (BAPA) solution (pre warmed to $37^{\circ} \mathrm{C}$ ), rapidly blown into each tube. The content, stirred immediately on a vortex mixer, and the tubes, replaced in the constant temperature bath. The reaction, terminated exactly 10 min later by blowing in $1 \mathrm{ml}$ of 30\% acetic acid with immediate mixing with a vortex mixer. A sample blank (the fourth tube containing sample extract), prepared by the same procedure except that the trypsin solution was added after the reaction termination by the addition of acetic acid. The absorbance of each solution was determined at $410 \mathrm{~nm}$ against the sample blank. Values obtained from each of the three sample extractsl, subtracted from the trypsin standard. These values, averaged, and the trypsin inhibitor content was determined from the following relationship:

$$
\text { TI, mg/g of sample }=\frac{\text { differential absorbance }}{0.019 \times 1.000} \times \text { dilution factor }
$$

$1 \mu \mathrm{g}$ of pure trypsin have an equivalent of 0.019 , absorbance units [16].

\section{Result and Discussions}

\subsection{Chemical Composition}

Results of the proximate composition of the seed flour and the protein isolates, presented in (Figure 1). The whole (WCF) and de-hulled defatted (DDCF) cowpea seed flour contained 22.30\% - 26.73\% protein; $2.10 \%-2.30 \%$ fat; $4.10 \%-1.02 \%$ fibre; $3.77 \%$ - 3.87\% ash and 60\% - 59\% carbohydrates, respectively (on dry weight basis) as major components (Table 1). The data obtained is comparable to that reported by [17] for four cow pea cultivars: $22.97 \%$ - 25.40\% protein, 3.24\% - 3.66\% fat, 5.66\% - 6.85\% crude fibre, and 56.50\% - 60.44\% carbohydrates.

Minerals: Minerals compositions for each of the whole and dehulled cowpea flour, shown in Table 2. Relatively small differences were observed between whole and de-hulled cowpea flour in their mineral content. The minerals K, Na and Ca were the major inorganic constituents of the ash in all studied samples. [18]-[20] reported similar finding.

Leguminous plants are good source of minerals and are higher in Ca than most cereals [21]. Therefore, cowpea seed could be used as supplementation for cereal flour to improve its Ca content. Cowpea seed flour had higher amounts K; Ca and Na. Calcium (essential for bone and teeth development) level was high in cowpea flour. Minerals in the studied samples, whole cowpea flour (WCF) and de-hulled defatted cowpea flour (DDCF)

Table 1. Proximate composition (\%) of whole cowpea flour (WCF), de-hulled defatted cowpea flour (DDCF) and protein isolates (CPIA) and (CPIB) on dry basis.

\begin{tabular}{cccccc}
\hline Chemical constituents & WCF & DDCF & CPIA & CPIB & LSD \\
\hline Crude protein $(\mathrm{N} \times 6.25)$ & $22.30 \mathrm{~d} \pm 0.20$ & $26.73 \mathrm{c} \pm 0.06$ & $75.0 \mathrm{~b} \pm 0.06$ & $76.0 \mathrm{a} \pm 0.12$ & 0.26 \\
Crude fat & $2.10 \mathrm{a} \pm 0.10$ & $2.30 \mathrm{a} \pm 0.10$ & Traces & Traces & 0.43 \\
Crude fibre & $4.10 \mathrm{a} \pm 0.20$ & $1.02 \mathrm{~b} \pm 0.08$ & Traces & Traces & 0.35 \\
Total ash & $3.77 \mathrm{a} \pm 0.06$ & $3.87 \mathrm{a} \pm 0.06$ & $2.63 \mathrm{~b} \pm 0.15$ & $2.3 \mathrm{~b} \pm 0.20$ & 0.55 \\
Carbohydrate (by difference) & $60.07 \mathrm{a} \pm 0.06$ & $59.78 \pm 0.28$ & $13.0 \mathrm{~b} \pm 0.17$ & $13.1 \mathrm{~b} \pm 0.0$ & 0.43 \\
\hline
\end{tabular}

Means in the same raw with different letters are significantly different $(\mathrm{P}<0.05)$. CPIA = Cowpea protein isolate by isoelectric point precipitation; CPIB = Cowpea protein isolate by micellization precipitation. 
Table 2. Minerals composition of whole and dehulled cowpea seed flours (WCF and DCF) (mg/100 gm sample).

\begin{tabular}{ccc}
\hline Element & Whole cowpea flour (WCF) & Dehulled cowpea flour (DCF) \\
\hline Macro element: & & \\
Potassium (K) & $29.25 \pm 0.71$ & $24.99 \pm 0.08$ \\
Sodium (Na) & $1.76 \pm 0.08$ & $1.0 \pm 0.07$ \\
Calcium (Ca) & $32.28 \pm 0.68$ & $33.61 \pm 0.79$ \\
Micro element: & & \\
Zinc (Zn) & $0.260 \pm 0.036$ & $1.22 \pm 1.545$ \\
Iron (Fe) & $0.004 \pm 0.001$ & $0.013 \pm 0.019$ \\
Copper (Cu) & $0.04 \pm 0.006$ & $0.25 \pm 0.012$ \\
Manganese (Mn) & $0.18 \pm 0.010$ & $0.30 \pm 0.006$ \\
\hline
\end{tabular}

Note: Crude fibre for WCF and DCF were $4.10 \%$ and $1.02 \%$, respectively.

were: calcium (32.38 - $33.61 \mathrm{mg} / 100 \mathrm{~g})$ potassium (29.25 - $24.99 \mathrm{mg} / 100 \mathrm{~g})$ and sodium (1.76 - $1.0 \mathrm{mg} / 100 \mathrm{~g})$. These values compare favorably with some reported values of cowpea varieties and utilized legumes, [22]-[25]. Among the trace elements the least abundant minerals in the studied samples were iron $(0.0040 .013 \mathrm{mg} / 100 \mathrm{~g})$ and copper (0.04 - $0.25 \mathrm{mg} / 100 \mathrm{~g}$ ). Sodium ranged between 1.17 - $1.0 \mathrm{mg} / 100 \mathrm{~g}$ for de-hulled and whole cowpea flour respectively, which is relatively lower than those reported for cowpea (6.5 - $13.4 \mathrm{mg} / 100 \mathrm{~g})$, [26]. IIn cowpea cultivars, calcium, zinc, and Iron were found in the range from 383.75 - 567.25; 32.34 - 34.71 and 33.44 - $35.63(\mathrm{mg} / \mathrm{kg})$, respectively [17]. A study carried on cowpea grains in Africa, [27] stated that it consist of Calcium, 958 - $992.4 \mathrm{mg} / \mathrm{kg}$; Zinc, 32.6 - $31.5 \mathrm{mg} / \mathrm{kg}$; while iron content ranged from 27.6 to $28.9 \mathrm{mg} / \mathrm{kg}$. Studying four cow pea cultivars, Calcium, Zinc, and Iron ranged from 383.8 - 567.3; 32.3 - 34.7 and 33.4 - 35.6 (mg/kg), respectively [28].

Tannin: content appears to be related to the color of the pericarp of the grain [29]. Since tannins, are located mainly in the testa or seed coats of cowpea physical removal of seed coat by either de-hulling or milling and separating hulls may decrease the tannin content in de-hulled cowpea and improve the nutritional quality. No tannins, observed in both cowpea protein isolates. Tannins are poly phenols and all poly phenolic compounds are water soluble in nature [30], then reduction in the tannin content may be attributed to leaching out of phenols during preparation of isolates. This is a good advantage regarding protein quality of cowpea seed. Tannin content percentages, using vanillin method for raw cowpea, decorticated and decorticated roasted cowpea was (0.76, 0.02 and 0.005), respectively [31].

\subsection{Anti-Nutritional Factors}

Table 3 illustrates some anti-nutritional compounds including trypsin inhibitor activity, tannins, and phytic acid content found in cowpea seed flours and protein isolates.

Tannins are complex poly phenolic compounds widely distributed in food and feeds of plant origin that have a large influence on nutritive value of forage legumes. Tannins in raw de-hulled cowpea and dehulled defatted cowpea flours were $0.004 \%$ and $0.003 \%$ respectively, these values are low compared to $(0.40 \%)$ for vegetable cowpea (Sesquipedalis) [32] and 175 - $590 \mathrm{mg} / 100 \mathrm{~g}$ for whole cowpea (Vigna sinensis. L.) [33] and 0.95\% $2.40 \%$ and $0.08 \%-0.32 \%$ for colored-flouring varieties and white-flowering varieties of faba beans (Vicia faba L.) respectively as reported by [34] [35] found a clear correlation between color of the flower, seed color and tannins content of faba beans. White-flowering varieties, with no pigments in the flowers, yield white and grey seeds with low tannins contents. Tannins values were reported to range from $0.0 \%$ to $0.7 \%$ for cowpea, pigeon peas and mung beans [36].

Phytate represents a complex class of naturally occurring compounds that can significantly influence the functional properties of foods. No phytate, observed in cowpea protein isolates (CPIA and CPIB) [37]. A significant $(\mathrm{P}<0.05)$ reduction of phytic acid of chickpea, founds the result of soaking. [38]. Cooking resulted in $60 \%$ and $50 \%$ ) reduction in phytic acid content of lentils and butter beans respectively, while for broad beans only $11 \%$ 
Table 3. Anti-nutritional factors of dehulled cowpea flour (DCF), dehulled defatted cowpea flour (DDCF) and protein isolates (CPIA and CPIB).

\begin{tabular}{ccccc}
\hline Type of product & Tanninsa \% & Phytic acida \% & Trypsin inhibitor activityb (TIU/g) & Crude protein \% \\
\hline Dehlled cowpea flour (DCF) & $0.004 \mathrm{a}$ & $0.80 \mathrm{~b}$ & - & - \\
Dehulled defatted cowpea flour (DDCF) & $0.003 \mathrm{~b}$ & $1.17 \mathrm{a}$ & $16640 \mathrm{a}$ & 26.7 \\
Cowpea protein isolate-A (CPIA) & 0.00 & 0.00 & $4293 \mathrm{~b}$ & 75 \\
Cowpea protein isolate-B (CPIB) & 0.00 & 0.00 & $4290 \mathrm{~b}$ & 76 \\
SEM \pm & 0.00018 & 0.0002 & 0.1323 & - \\
\hline
\end{tabular}

$\mathrm{SEM} \pm$ is standard error mean; a: Mean of triplicate determinations; b: Mean of fourth determinations; abc: Means within the same column with different superscripts are different $(\mathrm{P}<0.05)$. CPIA = Cowpea protein isolate by isoelectric point precipitation; CPIB = Cowpea protein isolate by micellization precipitation.

was lost as the result of cooking [39]; while reported values $(0.28 \%-0.41 \%)$ and $0.43 \%$ for raw soy bean and soy bean isolates respectively. The result of phytic acid content in the flour and both cowpea protein isolates, presented in Table 3. Phytic acid content of raw cowpea and dehulled defatted cowpea flour was $(0.80 \%$ $1.17 \%)$. Generally, this result, higher than those reported: $0.60 \%$ and $0.29 \%$ for raw and de-hulled cowpea respectively [40]. Meanwhile 4.25\%, reported for vegetable cowpea (Sesquipedalis) [32]. Values of 4.4\%, 14.6\%, $11.5 \%$ and $11.7 \%$ phytic acid for chick peas, black gram, black eyed beans and red kidney beans respectively, were reported [41] and (1.5\%) for broad beans [42]. Other values ranging from $0.3 \%$ to $1.7 \%$ phytic acid of dry legumes, chickpea (0.9\% - 1.1\%) and lentil (0.3\% - 0.4\%) [43], and phytic acid content of chickpea, $0.28 \%$ [44]. Variation in phytic acid content may be due to the effect of genetic, climatic and soil conditions.

De-hulling decrease the amount of phytic acid; it is recommended for cowpea before cooking where people are using them in great amounts, as in developing countries. Moreover, when such legumes are used for baby foods, de-hulling helps to prevent mineral deficiency.

Trypsin inhibitor is one of most important anti-nutritional factors present in plants particularly in legumes and reported to affect the nutritive value and protein digestibility. Significant difference $(P<0.05)$, observed between the raw cowpea flour and de-hulled defatted cowpea seed flour in their trypsin inhibitor activity of dehulled defatted cowpea seed flour was 16,640 TIU/g on dry weight basis (Table 2). $18850 \mathrm{TIU} / \mathrm{g}$ were found for raw cowpea [45]; 9035 TIU/g for cowpea flour [46], and 1113 TIU/g for raw vegetable cowpea seeds (Sesquipedalis), [32]. Analysis of 18 pea and five bean varieties for trypsin inhibitor activity gave values ranging from 0.15 to $4.62 \mathrm{TIU} / \mathrm{mg}$, [45]. It can be concluded that de-hulled defatted cowpea has considerably lower levels of for trypsin inhibitor activity than other peas. The level of trypsin inhibitor activity in cowpea protein isolates (CPIA and CPIB) were 4293 and 4290 TIU/g respectively. 18 TIU/g for cowpea protein isolate (CPI), [46] and faba bean contained $8.13 \mathrm{TIU} / \mathrm{mg}$ proteins [47]. It was shown that the anti-nutritional factors of cowpeas can be reduced and nutritional quality improved by plant breeding, de-hulling, heat treatment or supplementation of diets with enzymes [31]. Trypsin inhibitor (in TU units) was reported (1.68, 0.74 and 1.36), respectively for raw, decorticated and decorticated roasted cowpea seeds [31].

\section{Conclusions}

The abundant minerals in WCF and DCF were calcium (32.38 - $33.61 \mathrm{mg} / 100 \mathrm{~g})$; potassium (29.25 - 24.99 $\mathrm{mg} / 100 \mathrm{~g})$; and sodium (1.76 - $1.00 \mathrm{mg} / 100 \mathrm{~g})$. The least abundant minerals were iron (0.004 - $0.013 \mathrm{mg} / 100 \mathrm{~g})$; copper (0.04 - $0.25 \mathrm{mg} / 100 \mathrm{~g})$; manganese $(0.18-0.30 \mathrm{mg} / 100 \mathrm{~g})$ and zinc $(0.26-1.22 \mathrm{mg} / 100 \mathrm{~g})$; respectively. Trypsin inhibitor activity for RCF, CPIA and CPIB was found 16,640 TIU/g, $4293 \mathrm{TIU} / \mathrm{g}$ and $4290 \mathrm{TIU} / \mathrm{g}$ respectively. Condensed tannins in RCF and DDCF were found $0.003 \%$ and $0.004 \%$ respectively while phytic acid content $0.8 \%$ and $1.17 \%$ respectively, no phytic acid and tannins were observed in protein isolates.

Cowpea flour was also similar to other edible grain legumes in content of anti-nutritional factors; appropriate processing methods improved cowpea nutritive value and significantly reduced the levels of anti-nutritional factors.

\section{References}

[1] Rochfort, S. and Panozzo, J. (2007). Phytochemicals for Health, the Role of Pulses. Journal of Agricultural and Food 
Chemistry, 55, 7981-7994. http://dx.doi.org/10.1021/jf071704w

[2] Granito, M., Torres, A., Frías, J., Guerra, M. and Vidal-Valverde, C. (2005) Influence of Fermentation on the Nutritional Value of Two Varieties of Vigna sinensis. European Food Research and Technology, 220, 176-181. http://dx.doi.org/10.1007/s00217-004-1011-5

[3] Guillion, F. and Champ, M. (1966) Grain Legumes and Transit in Humans. Grain Legumes AEP, 11, 18-21.

[4] Sirtorti, C.R. and Lovati, M.R. (2001) Soy Proteins and Cardiovascular Disease. Current Atherosclerosis Reports, 3 , 47-53. http://dx.doi.org/10.1007/s11883-001-0010-2

[5] Prinyawiwatkul, W., McWatters, K.H., Beuchat, L.R. and Phillips, R.D. (1996) Cowpea Flour: A Potential Ingredient in Food Products. Critical Reviews in Food Science and Nutrition, 36, 413-429. http://dx.doi.org/10.1080/10408399609527734

[6] Frias, J., Diaz-Pollan, C., Hedley, C.L. and Vidal-Valverde, C. (1995) Evolution of Trypsin Inhibitor Activity during Germination of Lentils. Journal Agriculture Food chemistry, 43, 2231-2234. http://dx.doi.org/10.1021/jf00056a049

[7] Kozlowska, H., Honke, J., Sadowska, J., Frias, J. and Vidal-Valverde, C. (1996) Natural Fermentation of Lentils: Influence of Time, Concentration and Temperature on the Kinetics of Hydrolysis of Inositol Phosphates. Journal Science Food Agriculture, 71, 367-375. http://dx.doi.org/10.1002/(SICI)1097-0010(199607)71:3<367::AID-JSFA591>3.0.CO;2-I

[8] Thompson, L.U. (1977) Preparation and Evaluation of Mung Bean Protein Isolates. Journal Food Science, 42, 202206. http://dx.doi.org/10.1111/j.1365-2621.1977.tb01252.x

[9] McCurdy, S. and Kniptel, J. (1990) Investigation of Faba Bean Protein Recovery and Application to Pilot Scale Processing. Journal Food Science, 55, 10931094. http://dx.doi.org/10.1111/j.1365-2621.1990.tb01606.x

[10] Ferndez-Quintela, Q.A., Macarulla, M.T., Del Barrio, A.S. and Martinez. J.A. (1997) Composition and Functional Properties of Protein Isolates Obtained from Commercial Legumes Grown in Northern Spain. Plant Food Human Nutrition, 51, 331-342. http://dx.doi.org/10.1023/A:1007936930354

[11] Lampart-Szczapa, E. (1996) Preparation of Protein from Lupin Seeds. Nahrung, 40, 71-74. http://dx.doi.org/10.1002/food.19960400205

[12] Association of Official Analytical Chemists (1998) Official Method of Analysis. 16th Edition, AOAC, Washington DC.

[13] Price, M.L. and Bulter, L.G. (1978) Critical Evaluation of the Vanillin Reaction as an Assay for Tannin in Sorghum Grain. Journal Agriculture Food Chemistry, 26, 1214-1218. http://dx.doi.org/10.1021/jf60219a031

[14] Mohamed, A.I., Perera, P.A.J. and Hafez, Y.S. (1986) New Chromophone for Phytic Acid Determination. Cereal Chemistry, 63, 475-478.

[15] Hamerstrand, G.E., Black, L.T. and Glover, J.D. (1980) Trypsin Inhibitors in Soy Products: Modification of the Standard Analytical Procedure. Cereal Chemistry, 58, 42-45.

[16] Kakade, M.L. (1969) Unavailability of Cystine from Trypsin Inhibitors as a Factor Contributing to the Poor Nutritive Value of Navy Beans. Journal of Nutrition, 99, 34-42.

[17] Liyanage, R., Perere, O.S., Weththasinghe, P., Jayawardana, B.C., Vidanaarach, J.K. and Sivakanesan, R. (2014) Nutritional Cowpea Cultivars in Sri Lanka. Journal of Food Legumes, 27, 215-217.

[18] Muzquiz, M., Burbano, C., Rey, C. and Cassinello, M. (1989) A Chemical Study of Lupinus hispanicus Seed Nutritional Components. Journal of Science of Food and Agriculture, 17, 197-204. http://dx.doi.org/10.1002/jsfa.2740470207

[19] Dagnia, S.G., Petterson, D.S., Bell, R.R. and Flanagan, F.V. (1992) Germination Alters the Chemical Composition and Protein Quality of Lupin Seeds. Journal of Science of Food and Agriculture, 60, 419-423. http://dx.doi.org/10.1002/jsfa.2740600403

[20] Todorov, N.A., Pavolov, D.C. and Kostov, K.D. (1996) Lupinus spp. Legumes and Oil Seeds in Nutrition. Chapman and Hall, London.

[21] Osborn, T.W. (1977) Element Composition of Soy Bean Meal and Inter Laboratory Performance. Journal of Agriculture Food Chemistry, 25, 229-232. http://dx.doi.org/10.1021/jf60210a028

[22] Aletor, V.A. and Aladetimi, O.O. (1989) Compositional Evaluation of Some Cowpea Varieties and Some Under-Utilized Edible Legumes in Nigeria. Die Nahrung, 33, 99-107. http://dx.doi.org/10.1002/food.19890331023

[23] Olaofe, O., Umar, Y.O. and Adediran, G.O. (1993) The Effect of Nematicides on the Nutritive Value and Functional Properties of Cowpea Seeds. Food Chemistry, 46, 337-342. http://dx.doi.org/10.1016/0308-8146(93)90001-V

[24] Oke, D.B., Tew, O.O. and Fetuga, B.L. (1985) The Nutritional Composition of Some Cowpea Varieties. Nigerian Journal of Animal Production, 22, 32-36.

[25] Padilla, F.C., Alvaerez, M.T. and Alfaro, M.J. (1996) Functional Properties of Barinas Nut Flour Compared to Those 
of Soy Bean. Food Chemistry, 57, 191-196. http://dx.doi.org/10.1016/0308-8146(95)00108-5

[26] Aremue, O.M., Olorunfemi, O. and Akintayo, T.E. (2006) Compositional Evaluation of Cowpea (Vigna ungiculata) and Scarlet Runner Bean (Phaseolous coccineus) Varieties in Nigeria. Journal of Food, Agriculture and Environment, 4, 39-43.

[27] Mamiro, P.S., Mbwaga, A.M., Mamiro, D.P., Wand, M.A. and kinabo, J.L. (2011) Nutritional Quality and Utilization of Local and Improved Cowpea Varieties in Some Regions in Tanzania. African Journal of Food, Agriculture, Nutrition and Development, 11, 4490-4505. http://dx.doi.org/10.4314/ajfand.v11i1.65876

[28] Liyanage, R., Perere, O.S., Weththasinghe, P., Jayawardana, B.C., Vidanaarach, J.K. and Sivakanesan, R. (2014) Nutritional Properties and Antioxidant Content of Commonly Consumed Cowpea Cultivars in Sri Lanka. Journal of Food Legumes, 27, 215-217.

[29] Subramanian, V., Bulter, L.G., Jambunathan, R. and Prasada-Rao, K.E. (1983) Some Agronomic and Biochemical Characters of Brown Sorghum and Other Possible Role in Bird Resistance. Journal of Agriculture and Food Chemistry, 31, 1303-1307. http://dx.doi.org/10.1021/jf00120a039

[30] Kumar, N.R., Ready, A.N. and Rao, K.N. (1979) Levels of Phenolic Substance on the Leachionted in Cicezo Seed. Journal of Experimental Biology, 17, 114-116.

[31] Balail, N.G. (2014) Effect of De Cortication and Roasting on Trypsin Inhibitors and Tannin Contents of Cowpea (Vigna unguiculata L. Walp) Seeds. Pakistan Journal of Biological Sciences, 17, 864-867. http://dx.doi.org/10.3923/pjbs.2014.864.867

[32] Udensi, E.A., Ekwu, F.C. and Isinguzo, J.N. (2007) Antinutritional Factors of Vegetable Cowpea (Sesquipedalis) Seeds during Thermal Processing. Pakistan Journal of Nutrition, 6, 194-197. http://dx.doi.org/10.3923/pjn.2007.194.197

[33] Wang, P.X. and Ueberschar, K.H. (1990) The Estimation of Vicine, Convicine and Condensed Tannins in 22 Varieties of Faba Bean (Vicia faba L.). Animal Feed Science and Technology, 31, 157-165. http://dx.doi.org/10.1016/0377-8401(90)90121-N

[34] Cabrera, A. and Martin, A. (1986) Variation in Tannin Content in Vicia faba L. Journal of Agriculture and Food Chemistry, 30, 1087-1089. http://dx.doi.org/10.1017/s0021859600063978

[35] Price, M.L., Hagerman, A.E. and Butler, L.G. (1980) Tannin in Sorghum Grain: Effect of Cooking on Chemical Assays and on Antinutritional Properties in Rats. Nutrition Reports International, 21, 761-767.

[36] Eltinay, A.H., Mahgoub, S.O., Mohamed, B.E. and Hamad, M.A. (1989) Proximate Composition and Mineral and Phytate Content of Legumes Grown in Sudan. Journal of Food Composition and Analysis, 2, 69-78. http://dx.doi.org/10.1016/0889-1575(89)90065-3

[37] Elhardallou, S.B. and Walker, A.F. (1992) Binding of Iron by Three Starchy Legumes in the Presence of Iron Alone with Calcium, Zinc, Magnesium and Copper. International Journal of Food Science and Nutrition, 43, 61-68. http://dx.doi.org/10.3109/09637489209027533

[38] O’dell, B.L. (1979) Effect of Soy Protein on Trace Mineral Availability. In: Wilcke, H.L., Hopkins, D.T. and Waggle, D.H., Eds., Soy Proteins and Human Nutrition, Academic Press, New York, 187-207. http://dx.doi.org/10.1016/b978-0-12-751450-5.50016-4

[39] Reddy, N.R. and Sathe, S.K. and Salunkhe, D.K. (1982) Phytate in Legumes and Cereals. Advances in Food Research, 28, 1-18. http://dx.doi.org/10.1016/S0065-2628(08)60110-X

[40] Elhardallou, S.B., Eltinay A.H. and Nour, A.A.M. (1980) Chemical Characteristics of Some Legumes Grown in the Sudan. Sudan Journal of Food Science Technology, 12, 35-42.

[41] Eltinay, A.H., Mahgoub, S.O., Mohamed, B.E. and Hamad, M.A. (1989) Proximate Composition and Mineral and Phytate Content of Legumes Grown in Sudan. Journal of Food Composition and Analysis, 2, 69-78. http://dx.doi.org/10.1016/0889-1575(89)90065-3

[42] Kumar, N.R., Ready, A.N. and Rao, K.N. (1979) Levels of Phenolic Substance on the Leachionted in Cicezo Seed. Journal of Experimental Biology, 17, 114-116.

[43] Elkhalifa, E.A. (1997) Effect of Heat Treatment on Physico-Chemical and Functional Properties of Lablab Bean and Cowpea Flours and Their Utilization in Kisra and Bread Products. A Report of the Work Carried out under U.N.U. Fellowship, Central Food Technology Research Institute, Mysore.

[44] Phillips, R.D. (1982) Preparation and Composition of Dry Millet Flour from Cowpea. Journal of American Oil Chemists' Society, 59, 351-353. http://dx.doi.org/10.1007/BF02541018

[45] Griffiths, D.W. (1984) The Trypsin and Chymotrypsin Inhibitor Activities of Various Peas (Pisum spp.) and Field Bean (Vicia faba) Cultivars. The Journal of the Science of Food and Agriculture, 35, 481-486.

http://dx.doi.org/10.1002/jsfa.2740350502 
[46] Rangel, R., Saraiva, K., Schwengber, P., Narciso, M.S., Gilberto, B.D., Ferreira, S.T. and Pedrosa, C. (2003) Biological Evaluation of a Protein Isolate from Cowpea (Vigna ungiculata) Seeds. Food Chemistry, 87, 491-499. http://dx.doi.org/10.1016/j.foodchem.2003.12.023

[47] Khalil, A.H. and Mansour, E.H. (1995) The Effect of Cooking, Autoclaving and Germination on Nutritional Quality of Faba Beans. Food Chemistry, 54, 177-182. http://dx.doi.org/10.1016/0308-8146(95)00024-D

\section{Abbreviations}

WCF whole cowpea flour

DCF dehulled hydroxide cowpea flour

DDCF dehulled defatted cowpea flour

CPIA cowpea protein isolates (from DDCF) by isoelectric method

CPIB cowpea protein isolates (from DDCF) by micellization method

$\mathrm{HCl} \quad$ hydrochloric acid

$\mathrm{NaOH}$ sodium hydroxide 